\title{
Unspeakable Silences, When Poetry Ceases to be a Luxury, Black Tulips, My Eggs
}

\section{Melissa A. Castillo-Garsow, Yale University}

Melissa Castillo-Garsow is a Mexican-American writer, journalist, and scholar currently pursuing a $\mathrm{PhD}$ in American Studies and African American Studies at Yale University. Her short stories and poetry have been published in various journals including The Acentos Review, La Bloga, Hispanic Culture Review, and Hinchas de Poesia. Her first novel, Pure Bronx, co-written with Fordham Professor Mark Naison, is due for release in October 2013 from Augustus Publishing.

Melissa completed her Master's degree in English with a concentration in Creative Writing at Fordham University in 2011. Prior to that she was awarded a Bachelor of Arts from New York University summa cum laude with a double major in Journalism and Latin American Studies. A former employee of NBC News, El Diario/La Prensa and Launch Radio Networks, Melissa has had articles and reviews published in a wide variety of forums including CNN.com, Latin Beat Magazine, University Wire, El Diario/La Prensa, Women's Studies, Words. Beats. Life: The Global Journal of HipHop Culture, and The Bilingual Review. Melissa is an active scholar in the fields of English literature, American Studies, African American Studies and Latin American/Latino Studies. At Yale, she focuses on the study of Afro-Latino history and culture in the 20th Century. 


\section{Unspeakable Silences}

She asks me,

are you doing the work?

She already knows the answer.

I am still afraid

to say

one drink didn't knock me out

a golden glittered breast

didn't put me on my back

an expensive dinner

didn't change what that was.

I am still living in unspeakable spaces.

Still waking up to that glass

still pretending its reflection

doesn't relight that flame somehow

convinced

if I portray that warrior on my back

I will become her.

But my unspeakables define medrain the light from my eyes like those 'episodes' drain my bank and what I've said has never transformed me. Maybe,

I said it to the wrong people.

Maybe,

my silences can't be spokenthey need to be screamed.

I am a scarred woman, I've drawn battle lines more than once, lost most of the time.

As a Latina, I should push the scars away, embrace every curve pray for an arroz y gandules behind love how I jiggle. But this is our secretwe terrorize our bodies as much as anyone die in endless parades of beauty just usually, with less money.

This is my secret.

When I came out as Latina, the mirror laughed harder mocked my eyelined insecurities, 
taunted me with preguntas:

Can you really keep up this lie about eating tortillas?

It is a generation of anythings we are told we can do anything be anything.

Nobody told me anything could kill possibilities turned to cold sweats vomits, pills, hospitals, doctors diagnosis.

How many Hail Mary’s, father?

Now silence is my penance my knuckles bitten and tender my face crushed against pavement my body pinned to the floor.

I wish I could call myself

a black feminist lesbian mother warrior a chicana dyke-feminist, tejana patlache poet but I don't know how to be her except to feel her warmed breath over worn pages I am stuck where she tells me I'm in danger.

I'm terrified to share her passions, afraid to stretch out wide, afraid to confront my addictions, still worried I won't be able to explain a pain that kills a pain that drives a pen to paper a pain that made the needle feel like relief.

I am no warrior. I am a survivor.

Fifteen years since I first bloodied my knuckles my hands are still bleeding my skin is raw and I am here etching this lifeline from belly button to index finger avoiding scabs if I need to.

I display my truths at the alter in barely there metaphors unblinded by all that is missingsugared skulls, pan dulce the pictures of the deadI could only manage fruit this time. 
In silence I inscribed Mexico on hip slender graceful chili peppers

hidden under winter layers because

I was tongue tied when

cousins made fun of my acento

when

classmates made fun of my father's

when

professor said there was too much Spanish

when

my poetry was tweeted 'too Latino'

I said nothing and now,

I write everything

protected

by the two eyes looking

out from my back

dark and discerning

she is my ancient mother,

my warrior.

So here is my (self) diagnosis.

I am a poet survivor.

Was it the second time I was told

I was standing on the edge or

the third or fifth?

For some reason I have survived

lived

to feel this pain and explain it

to find this silence and

disobey it.

Here's the real unspeakable.

I am angry on this page.

Because

I never thought about living

and now

I pray my body keeps going.

Because

I am angry for those

days nights hours minutes

confined by my mind

(I refuse it's my mind)

that left me tied down

tortured-as if

I were an addict.

I am not an addict

and never have been

because now,

He asks me to forget 
crashing plates

the reverberation of

hour long tirades

the trembling fear

or the summer

that cemented 15 years

of wasted promises-

I wouldn't if I could.

Because now,

they tell me it was

the wrong DNA

faulty wiring

some accident of upbringing

chance - and I am angrier.

So I'll say it.

Some words have become empty in my life and they called me a little Mexican hipster-

Little. When all

I wanted was to write a big poem but

big is someone who does not shrink

away and

I've perfected the art of silence

each day I practiced saying one thing less

my mouth a mess of peanut

butter cotton balls lodged

in my esophagus.

But sorry is for those

who can't pronounce

lo siento and lo siento has grown old

and honestly,

my silence could last a lifetime.

The skulls come at me

laughing

taunting

pushing me to dodge a serpent

dodge the serpents stumble

into snake lady who

inspires everything-

but death and

I've stopped ducking.

I've hidden for decades already

played the chorus to your lives, besides

Can you really blame me for what I've done? 
When Poetry Ceases to be a Luxury

If poetry is what I feel and theory what I know, why do I only feel that I know on the blank space of this page between words amongst images - thereI am no longer broken

Poetry was like exercise a whim discarded with guilt until I stopped protecting myself from him from his inattention and gave myself over to her if only for a stanza

I stretched myself to her let her brush my hair wash my back peel me like an orange and expose my seeds

I tried to hide that messy fleshy matter but she knows crumbles up the page crosses out the abusive lines I cannot lie to her.

I used to write on my side until I realized my side was my center planted where I never wanted to dig beneath distrusted dreams I covered in vulnerabilities of rings and bangs

A paralytic poetry of world travels in linguistic trickery-immobilizeduntil I accepted my sickness accepted that it didn't define me accepted a different voice

A softer voice hoarse from shouting over headphones worn down by doubt washed away by fluids I put my ear to the ground and heard nothing stuck a stethoscope to my 
heart and heard a murmur

She can't live in my body anymore

but sometimes,

she sits beside me at the window

washes my hair in the shower

lies beside me in bed chanting

Poetry will be ... will be ... 


\section{Black Tulips}

Reconfigure

Reengage

this constructed decentralization

a postmodern aesthetic

textured both

autobiographically and autographically

the transparence and opacity

of its diachronic synchronicity-

an intentional catachresis

Essentially

nothing -

when did it stop meaning

the green blades you bled on

make sense

the black tulips you kissed

of the mountains of bloody leaves crushed

beneath the weight of two bodies

intertwined-

like linked chains or

candy necklaces that get eaten

one by one.

The soft cushion of an uncut lawn.

I pick up a black tulip and press it in my book.

I pick up a blood stained blade and put it in my book. 


\section{My Eggs}

Name her to me.

I pull up a seat at the table, smooth the tablecloth, crack an egg, but it is bloody inside.

She evades. Defining womanhood. Sanitized.

Is anything sacred?

Shocks me to remember. A slave in the North. When slaves were men and women were white.

Unwomaned. She slides away into the shadows. Another white girl painted brown, another truth violated.

But she also sees:

(auto)biography, respectability, authenticity.

Tell her to me.

Poach me an egg. Tender and slow so I can feel the stillness of a little room, a big parlor.

Endures the slippage from the porch, the unhealed scars of the flesh, still the marketing of her flesh, crammed into a crammed living space, she talks sweet instead.

Attend to her.

I learned language from eggs, learned meaning from eggs, when language was wonder full.

Uovo. Huevo. Egg.

Call her to me.

Every body has its out. Every flesh has its scars. Every imagination it's possibilities, Every beginning should have its egg.

But she can imagine without possibilities. Return the gaze without lifting her eye.

Birth without gaining a pound. Stand off.

Fertilize me.

Bring her to me.

Leave it runny. I'll scramble it with chicharrón and let the yolk seep into that hard skin until it is tender and chewable. 
Salty sweet. Fancy Sweet. Shadowy Stone. Shimmering Bone. Fake fuss. I polite cuss.

What was never and is not.

So she writes her way into being. Tells on him, tells on her.

Read: there's too much sex here.

Read: she's scrambling sex here.

Read: my private has to be made public.

Read: I'm gendering my ungender.

Sing her to me.

Forget nothing.

the warring triples, a serpent's tongue lashing at her peeping ways and then drawn together under a wide skirt, across tables, across countries, bundled in a wide sarape in the heart of the border, wading across the rivers of sunburnt imperialism.

Because one is never quite finished. 